\title{
PALANQUINS ON CAMELS AND ELEPHANTS IN THE ISLAMIC WORLD*
}

\author{
Serena Paolini - Independent scholar, Rome
}

This article analyses the different types of palanquins on camels or elephants used in the Islamic era, paying specific attention to their appearance and evolution over time, their practical function, the use context, the symbolic (religious or political) connotation, and the presence of one or more male or female figures. The almost exclusive use of camels for females and elephants for males (except for palanquins with small pointed pillars), presumably for both practical and symbolic reasons, is notable. In the case of palanquins accommodating more than one person, gender does not seem related to the animal, even though the context (war, ceremony, caravan etc.) usually changes. Lastly, empty palanquins (i.e. those without a traveller, sometimes bearing sacred objects) on camels had a specific symbolic role closely related to both the religious and socio-political spheres.

Keywords: Islamic art; palanquin; camel; elephant; iconography

\section{INTRODUCTION}

Palanquins in the Islamic world have both practical and symbolic meanings: they were used by passengers to protect themselves from prying eyes and danger, or to show their rank and wealth; palanquins represent as well a symbol of royal power.

The animals often chosen to carry the palanquins also bear this double meaning. Both camels and elephants are indeed known for their strength, but they also play a similar social role in two opposite areas of the Islamic world as symbols of, respectively, Arabs and Indians. They also represent secular power and were especially used in ancient times by the army commander, often the sovereign himself, to reach the battle camp, whereas during the fight he would ride on horseback.

\section{PALANQUINS ON CAMELS}

\subsection{The women's hawda}

Since the pre-Islamic era, palanquins mounted on camels have been used to carry women of high rank, and in the literary sources they are already mentioned in relation to the Prophet's wives (especially the third, ' $\bar{A}$ ' isha bint Abī Bakr). These types of camel-litters are «made of hoops arranged to form a dome and draped with hangings to screen the travellers from prying glances», ${ }^{1}$ as shown in the figurative representations (fig. 1). Most of them are miniatures and depict a standardised palanquin with a square base, usually covered by a dome (sometimes positioned at the centre of a flat cover; the palanquin is seldom covered by a pyramid).

The only significant variation in the women's hawda iconography is the hexagonal base, which appears from the second half of the $16^{\text {th }}$ century (it is of interest to note that the same shape also appears on palanquins carried by elephants at around the same time). ${ }^{2}$

\footnotetext{
This paper is based on the author's MA thesis, Sapienza University, 2016.

1 Pellat 1971, 667.

2 See for example three miniature paintings: one depicting the meeting between Bahrām and Sapinūd, from a manuscript of the Shāhnāma by Firdawsī made in Shiraz (Iran) around 1550-1560, now in the Kraus Collection, f. 339r (Grube 1972, ill. on pl. XXXI); one depicting Yūsuf's enchantment and Zuleikha's arrival,
} 
2.2. The empty seat: qubba, 'uṭa, mạ̣mal

In the Arabian Peninsula palanquins without a traveller, sometimes containing objects with high symbolic value, have been used since the pre-Islamic era.

The earliest one known to scholars was called a qubba: a small, domed tent, made of red leather, which was used as a tabernacle for one or two sacred betyls, carried by a 'sacred' camel during mass movements, religious processions and even into major battles. ${ }^{3}$

After the beginning of the Islamic era the same meaning as a symbol of power and emblem of the tribe is found again in the so-called 'utfa litter, similarly brought into battle and defended to the very end.

From the $13^{\text {th }}$ century it also applies to the mahmal, a tent-like camel-litter originally housing the richly embroidered cloths that cover the Ka ba. It was first sent with the Egyptian pilgrimage caravan to Мecca in 1266 by Mamluk Sultan Baybars to proclaim him as protector of the Holy Places and it remained in use until $1926 .{ }^{4}$ Its significance was in fact political in spite of the religious context of the pilgrimage, which is rather clear considering that in the following years the mahmal was usually empty. These kinds of palanquins are similarly described, the 'utfa as «ein aus festem Holze gearbeitetes, länglich viereckiges, fast ovales und mit Straussfedern reich geschmücktes Gitterwerk, welches auf dem Rücken eines starken, gleichfalls aufgeputzten Kameels befestigt wird», ${ }^{5}$ and the mahmal

built of wood and approximately cubic, broader (1m 75) than they were long (1m 35), surmounted by a four-faced pyramid, with, in the upper angles of the cube, four gilded balls and on top of the pyramid, a much larger ball surmounted by a stem, a star and a crescent: the whole was covered in an embroidered material. ${ }^{6}$

The palanquins depicted in two miniatures from a well-known manuscript of the Maqāmāt of al-Harīī produced in 1237 in Baghdad (Iraq), showing a caravan (fig. 2), fit this description particularly well.

\subsection{The double litter (maḥāra)}

For pilgrimages and other long journeys, Muslims often used different kinds of palanquins placed on camels (like the afore mentioned women's hawda). The main Arabic

from a manuscript of the Haft Awrang by Jāmī made in Qazvin (Iran) in the second half of the $16^{\text {th }}$ century, now in the Biblioteca Casanatense, Roma, Ms. 2002, f. 77v (Bernardini 1993, ill on p. 371) and one depicting Zuleikha's arrival into Memphis, from a manuscript of the Haft Awrang by Jāmī made in Mashhad (Iran) in 1555-65, now in the Freer Gallery of Art, Washington D.C., inv. 46.12, fol.100v (Canby 1990, ill on p. 102)

3 Ettinghausen 1954; Lammens 1928.

4 Buhl - Jomier 1991.

5 Wetzstein 1878, 389. Morgenstern (1942, 160) reports this passage in the following way: «a lattice-work object, made of strong wood, four-cornered, of greater length than width, and almost oval in shape, which is fastened upon the back of a strong, decorated camel».

6 Buhl - Jomier 1991, 45. 
source regarding travels is Ibn Batțuttạ's work, known as Rihla (journey, travel). ${ }^{7}$ This text, commissioned in the $14^{\text {th }}$ century by Abū 'Inān Fāris (1329-1358), sovereign of the Mārinid dynasty of Morocco, describes the author's pilgrimages and voyages of exploration between Africa, Asia, China and Southeast Asia. Ibn Batțutata mentions a peculiar type of palanquin consisting of a double litter, one half of which can be rented by the traveller: «en quittant la Mecque, le susdit émir Albahluwàn loua, pour me transporter jusqu'à Baghdad, une moitié de ces doubles litières en forme de paniers; il en paya le prix de son argent et me reçut sous sa protection; [...] lorsque je voulus partir de Khârezm, je louai des chameaux et j'achetai une double litière. J'avais pour contre-poids, dans un des côtés de cette litière, 'Afif eddîn Attaouzéry». ${ }^{8}$

The term used by Ibn Battututa is mahāra, the etymology of which refers specifically to the presence of two distinct parts, as in the oyster, i.e. a shell made of two valves: in fact the term mahāra is also used to define the oyster. ${ }^{9}$ The actual shape of this "double litter" is not described in detail in the literary sources, but it can be reconstructed thanks to a comparison with some representations of camels carrying two human figures made in Iraq and dating back to the $13^{\text {th }}$ century. A representation of this subject is found on the socalled "Blacas ewer", made in Mosul in 1232: a medallion on the body shows two figures in a camel-litter, a wealthy lady and a smaller, bearded man (fig. 3).

Other depictions of this "double litter" can be found in manuscripts from the same area and era (including the aforementioned Maqāmāt of al-Harīīi), but a clearer and more realistic representation of this type of palanquin is shown in a miniature from a copy of the Shāhnāma-yi Selīm Khān by Luqmān (which narrates the events of the kingdom of Selīm II, Ottoman sultan from 1566 to 1574), showing the murder of Ma 'ṣūm Beg Șafavī during the pilgrimage in 1567 (fig. 4). In the background of the main scene two camels are depicted, among those of other travellers, carrying two figures (male or female) each, sitting in trapezoidal baskets suspended one on each side of the camel and separated by the hump.

These characteristics are consistent with the information provided in the other sources mentioned above, in particular Ibn Baț̣uṭạ's suggestion of a "counterweight"; the smaller size of the male figure on the "Blacas ewer" could possibly denote its distance from the viewer.

\section{PALANQUINS ON ELEPHANTS}

\subsection{The throne (takht)}

The Persian term takht is used in Islamic literary sources to designate both the sovereign's throne and a throne-like seat placed on the back of an elephant on special occasions, such as pitched battles and ceremonial processions. ${ }^{10}$ Like the throne, the

\footnotetext{
Its full title is Tuhfat al-nazāar fi gharā'ib al-amșār wa 'ajā'ib al-asfār (A gift to those who contemplate the wonders of cities and the marvels of travelling).

8 Ibn Batțūṭa 1874, I, 404 and III, 19.

9 Lane 1968

10 Firdawsī 1976; Ibn Batțūṭa 1874.
} 
elephant was a status symbol in both native India and Iran, as it was considered a royal monopoly. $^{11}$

The main Persian epic poem, the Shāhnāma (Book of Kings), written by Firdawsī between 977 and 1010, often mentions takhts, sometimes specifically identified with the king's throne, which was brought along in battle. This custom seems to be confirmed by iconographic sources, especially miniatures, where royal thrones placed in buildings and takhts on elephants are very similarly represented. However, it is worth recalling that the author could have taken some poetic and artistic liberties, and it is therefore possible that a major throne remained inside the royal palace while one (or more) movable seats, resembling the throne but suitable for transportation, accompanied the king in his conquest.

Another interesting piece of information provided by Firdawsi is that the sovereign dominated the battlefield on his richly caparisoned elephant, from which he would give orders to the troops through various kinds of signals (in particular, a ball thrown inside a cup was the command to attack, but drums, trumpets, flags were also used) but if he had to join the combat himself he would mount his horse (probably for practical reasons such as more speed and freedom of movement). This custom was probably common in the $10^{\text {th }}$ century and projected by Firdawsī into a semi-mythical past, but it apparently changed at a later date as the absence of the commander from his habitual seat on the elephant would discourage his troops, who would believe him to have fallen in battle thereby determining his defeat. ${ }^{12}$ In miniatures, however, it is more common to see a representation of the sovereign enthroned on the elephant even if he is engaged in combat (probably because this would have had a stronger effect), equipped with a ranged weapon such as bow or lasso.

The analysis of the iconographic sources (especially miniatures) clearly reveals that the shape of the takht on elephants changed over time, with some recurring types.

The earliest and most common type (represented from the $14^{\text {th }}$ to the $18^{\text {th }}$ century, fig. 5) has a large, square-proportioned backrest with two movable side elements that can be closed to protect the vulnerable flanks of the sovereign. The shape of the base is not quite clear: in the earliest miniatures the lack of perspective makes it impossible to discern it from the two-dimensional block of the palanquin, and in some later representations it appears to be hexagonal when considering the front part but the backrest has just one side and there is no element suggesting depth.

A new type of takht starts appearing in miniatures from the beginning of the $15^{\text {th }}$ century (fig. 6): this is a simple, square-shaped, seat-like throne, made up of three sides of the same height; it can be bare or feature refined decoration. During the same period, an even simpler throne type can be found for the first time, consisting of a low quadrangular parapet (completely bare or soberly decorated) on which the sovereign is seated (a sort of

1 Ruska et al. 1965.

12 «The death or disappearance of the leader usually meant the loss of the campaign; thus in the battle of Samogarh, already mentioned above [battle between Dārā Shikōh and Awrangzīb, sons of the Mughal emperor Shāh Jahān, which took place in 1658], Dara lost the day after the hawda of his elephant had been struck by a rocket and he mounted a horse instead: his troops saw the empty hawda and believed their commander to have fallen» (Khadduri et al. 1971, 202). 
square “box”). In addition, some peculiar takhts are shown as hybrids of several types, creating thrones with different featured items assembled together. ${ }^{13}$

A completely new typology emerges in miniatures dated between the end of the $15^{\text {th }}$ and beginning of the $16^{\text {th }}$ century, very similar in shape to the hawda on a camel: it is a squarebased structure with a flat cover and a dome positioned at its centre, either having one or more arches up front, or fully open with only angular pillars to support the roof. ${ }^{14}$ These illustrations can be compared with earlier ceramic figurines, ${ }^{15}$ so that this type of takht, which could have been used during battles (having the advantage of bestowing the sovereign with more protection and visibility), can be dated back to the $13^{\text {th }}$ century. Around 1530 a further variant is portrayed in miniatures: a throne with a hexagonal base, completely closed or open up front, sometimes with a high backrest or covering structure (topped by a flat cover with a central dome). ${ }^{16}$ Such types of elephant thrones continued to be depicted until the $17^{\text {th }}$ and $18^{\text {th }}$ centuries, when the later and typically Indian form of the “double” seat (covered "in pavilion" or uncovered) spread; the "double seat" includes a rear, smaller and sometimes lowered portion usually reserved for the sovereign's orderly. ${ }^{17}$

\subsection{The palanquin with small pointed pillars}

A fairly homogeneous group of ceramics from Iran dated to the $12^{\text {th }}$ and $13^{\text {th }}$ centuries show a peculiar type of palanquin on an elephant, characterized by two small lateral pointed pillars. This subject is represented on tiles, moulded in relief and glazed (but rather difficult to read due to the state of preservation),$^{18}$ and depicted (or engobed) ${ }^{19}$ on bowls (and one dish), ${ }^{20}$ all showing a royal figure on an elephant, sometimes with one or more attendants.

The subject of this composition was identified as the return of Bahrām Gūr and his bride Sapinūd from India, narrated by Firdawsī in the Shāhnāma; Sapinūd (or, according to other scholars, Bahrām Gūr) would be depicted inside the palanquin, whereas the sovereign could

13 See for example the miniature painting depicting the battle between Rustam and Kamus, from a manuscript of the Shāhnāma by Firdawsī, the so-called "Shāhnāma of Shāh Tahmāsp", made in Tabriz (Iran) around 1530, f. 271r, now in the Tehran Museum of Contemporary Art, Tehran (Canby - Thompson 2004, ill. on p. 97).

14 See for example two miniature paintings: one depicting Khusraw on the battlefield, from a manuscript of the Khamsa by Nizāmī made in Herat (Afghanistan), late $15^{\text {th }}$-early $16^{\text {th }}$ century, now in the Salarjang Museum, Hyderabad, inv. no. 990, f. 290r (Suleimanov - Suleimanova 1983, ill. on p. 56) and one depicting Rustam killing Ashkabus, from a manuscript of the Shāhnāma by Firdawsī produced in Shiraz (Iran) around 1510, now in the Cleveland Museum of Art, Cleveland, inv. no. 60.199 (Grube 1974, ill. on p. 385).

15 See for example the ceramic figurine of an elephant made in Iran at the beginning of the $13^{\text {th }}$ century, now in the Freer Gallery of Art, Washington D.C., inv. n. 67.26 (Fehervari 1985, ill. on p. 134).

16 See for example two miniature paintings: one depicting the battle between Garshāsp and Jaipal, from a manuscript of the Garshāspnāma by Asadi made in Qazvin (Iran) in 1573, now in the British Library, London, Or. 12985, f. 28r (Canby 1993, ill. on p. 86) and one depicting the battle between Khusraw and Bahrām Chūbīn, from a manuscript of the Khamsa by Nizāāī made in Tabriz (Iran) between 1539 and 1543, now in the National Museum of Scotland, Edinburgh, n. 1898-70 (Canby - Thompson 2004, ill. on p. 120).

17 See for example the miniature painting depicting the battle between Khusraw and Bahrām Chūbīn, from a manuscript of the Khamsa by Niz̄āmī made in 1706, now in the M.E. Saltykov-Shchedrin's State Public Library, Saint Petersburg, SPL PNS 306, fol. 82r (Adamova - Greck 1976, pl. 59).

18 See for example the tile made in Iran (probably in Takht-i Sulaymān) around 1270, now in the Los Angeles County Museum of Art, Los Angeles, M.73.5.222 (Komaroff - Carboni 2002, ill. on p. 98).

19 Soustiel 1985, ill. on p. 102.

20 Rogers 2000, ill. on p. 202. 
be identified as the figure leading or following the elephant, when present. It is necessary, however, to point out that the Shāhnāma description differs significantly from these figurative representations, as Firdawsī mentions a horse instead of an elephant, which would not have gone unnoticed by Shangul, father of Sapinūd, who did not look favourably upon the marriage:
At dawn
He left Kannúj and hurried to the place
Of feasting. When 'twas night said Sháh Bahrám:
«Tis time to go, good wife!»
He seated her
Upon her palfrey and invoked God's name
O’er her in ancient Persian, donned his mail,
And mounted too, his lasso in the straps,
And mace in hand. He hurried to the river,
And found the merchants sleeping. Rousing them
He gat a skiff in readiness wherein
He seated Sapinud. With day begun
They came to land, and brightly shone the sun. ${ }^{21}$

However, it is not unusual to find these kinds of variants in illustrations of ArabicPersian literature for the most varied reasons; in this case probably to emphasise the Indian origin of Bahrām Gūr's bride by representing this exotic animal.

A rather complex composition that can be linked to this episode of the Shâhnama is depicted on two bowls dated 1218 and 1220 (fig. 7). The scene occupies the entire inner surface of the object (excluding a narrow band along the edge) and consists of five human figures, three of which are perched on the elephant's back dominating the centre of the composition, and two are positioned sideways. The one on the left is depicted leading the elephant, guided by the mahut who sits on its neck; the palanquin carrying the royal character is behind him, while on the back of the animal there is a kneeling figure (perhaps an attendant holding a small shield with his right arm) turning his head back to face the last character, dressed in a long striped tunic and presumably carrying an almond-shaped shield. A hint of background completes the scene: two phytomorphic elements and a small pond can be seen beneath the elephant's legs. The figure that follows the elephant could be identified with an armoured Bahrām Gūr and the stretch of water that the animal seems to overcome could be the river mentioned in the poem as the boundary between the kingdom of Shangul (father of Sapinūd and king of India) and Iran.

Other bowls bear less crowded compositions (fig. 8), but there can be no certainty about the character's identification with either Bahrām Gūr, Sapinūd (only one of the illustrations undoubtedly shows a woman) or a different character such as a "type" of royal figure depicted for aesthetic reasons.

This latter hypothesis could be supported by the typological analysis of the palanquin, which could be a variation of the takht (the sovereign's throne) and is comparable in particular with some typologies such as the seat-like and square "box" ones which

21 Firdawsī 1905, VII, 134. 
characterise miniatures from the $15^{\text {th }}$ century, whose angular pillars frequently have a pointed end. ${ }^{22}$ The larger proportions of this latter element in ceramic representations may therefore be due to purely aesthetic reasons (i.e. to match the object's shape) or they may show a typological variant of the takht prior to the first illustrated manuscripts. Other major differences concern the colours (with the prevailing use of blue, red and metallic shades of lustre paint, when the decoration is not monochromatic) and the positioning of the palanquin, which is lower than that depicted on paper. The upper edge, in fact, matches the line of the elephant's back or is slightly higher, whereas the base of the side pillars sometimes reaches the half of the animal's body (legs excluded); the figure inside is only represented as a half-bust and often appears rather disproportionate (perhaps to emphasize the royal character while maintaining some harmony with the shape of the object).

This could therefore represent a different type of palanquin on an elephant, described by Burton-Page as «a long platform from which the passengers' legs hang over each side», ${ }^{23}$ which does not appear in the miniatures of the following period. This platform would then have been placed directly on the back of the elephant (which is shown covered by the palanquin's upper edge, often decorated), while the lower part seen flanking the animal would support and protect the legs of the transported person, who would be sitting astride as if he/she was on a saddle instead of a seat or a flat pillow.

\subsection{Palanquins hosting more than one person}

Although palanquins on elephants usually only accommodate one person (male or female of royal rank), various representations depicted it as hosting two, three or more figures. A fairly homogeneous group consists of ceramic figurines (fig. 9) dated to the $12^{\text {th }}$ $13^{\text {th }}$ century which have been variously interpreted as water-jugs, oil lamps, models or statuettes with a purely decorative function, shaped as an elephant with a quadrangularbased hawda with an open-work parapet, surmounted by a sort of arched pavilion. This structure is made up of four corner supports with open-work circular motifs that merge at the centre creating a pointed arch profile; the result appears airy and light. The composition is completed by large shields covering the ears of the animal, whose head is in open-work to resemble a crown, and by the mahut who leads it. In some samples one or more figures in the palanquin can be identified as musicians (probably playing trumpets and drums).

To place various kinds of musical instruments on elephants' (or even camels') backs, to accompany celebrations or spur them on to battle, is a custom known from both literary and iconographic sources.

In the Shāhnāma, for example, when narrating war episodes Firdawsī insists a lot on the auditory aspect: drums, bells and trumpets were used to give signals and orders, inflame and incite soldiers to battle and at the same time terrorise the enemies.

Palanquins on battlefields housed both people outside the military sphere (such as astrologists and the sovereign's wives and favourite children) and soldiers, providing them

22 See for example the miniature painting depicting Kay-Khusraw mounted on an elephant, from a manuscript of the Shāhnāma by Firdawsī made in Lāhijān (Iran) between 1493 and 1494, now in the Art and History Trust Collection, Houston (Soudavar 1992, ill. on p. 142).

23 Burton-Page 1993, 932 
with a high and relatively secure position, and the elephants themselves were used both as a defence and an offense weapon (their charge was destructive and very difficult to stop):

At all times the centre was where the ruler or his deputy took his station, accompanied by the 'ulamâ', physicians, astrologers, etc., and the personal bodyguard; and this was the usual station for the elephants, certainly at least the ceremonial elephants carrying the standards and the čatra and those carrying bands of musicians. Wives or favourite children not infrequently accompanied the royal commander in the hawda of his elephant, although Awrangzib deprecated this practice, declaring that unnecessary persons round the commander hindered efficient leadership and organization. The chain of command was passed from the commander to all branches of the army through adjutants (tawāči, yasāwal, sazāwal), who were also responsible for ensuring that proper battle array and battle discipline were maintained; the orders might be communicated through flag signals, drum-beat or trumpet-blast, as well as by couriers. [...] The usual place of the elephants, however, was in the centre protecting the king. They were armoured with iron sheets, and carried hawdas in the form of armoured turrets in which sat archers, naphthathrowers and operators of projectile engines - an Indian device adopted by the Muslims which goes back in time to the 4th or 3rd century B.C. and persisted certainly into Mughal times $[\ldots]$.

A force would aim to create panic among its opponents first by an incessant rain of arrows, from cavalry, infantry, and from the hawdas of the elephants; these included poisoned and incendiary arrows.

Mandjanīks carried in the hawdas were similarly used to discharge large stones and naphtha-containers at the enemy. An early elephantcharge was also employed with the intention of spreading panic, after which the other arms would engage. ${ }^{24}$

\section{CONCLUSIONS}

This study shows the almost exclusive use of the camel for female figures and of the elephant for males (except for the type with pointed pillars), presumably due to a combination of both practical (i.e. the need for women to be completely protected from the glances of passers-by, achieved by use of a covered and curtained structure, which can easily be placed on the back of a camel rather than an elephant, very uncommon in Western areas) and symbolic reasons (the elephant has a distinctly regal connotation, being considered a royal monopoly).

Conversely, when there are more characters (apparently never in mixed groups), gender seems irrelevant in relation to the animal, though usually the context changes (war, ceremonial, caravan...). It is interesting to note that the importance of the "empty" seat (or palanquin containing sacred objects), which had a symbolic role closely linked to both the

24 Khadduri et al. 1971, 200-201. 
religious and socio-political spheres, was typical of the Near and Middle East and was mounted exclusively on a camel.

This is preliminary research which should be followed by more specific studies on individual types of palanquins and their interpretations, specific groups or categories of objects, information that can be found in literary sources, or particular practical or symbolic aspects of the palanquins themselves.

\section{REFERENCES}

AdAMOVA, A.T. - GRECK, T.

1976 Miniatures from Kashmirian Manuscripts, Sankt-Peterburg 1976.

BERNARDINI, M.

1993 Yusuf u Zuleykha (Giuseppe e Zuleyka) di 'Abd al-Rahman Jami': G. CuRATOLA (ed.), Eredità dell'Islam, Arte islamica in Italia, Venezia 1993, pp. 370-372.

BuHL, F. - JOMIER, J.

1991 Maḥmal: Encyclopaedia of Islam² VI, Leiden 1991, pp. 44-46.

BuRTON-PAGE, J.

1993 Nakl: Encyclopaedia of Islam ${ }^{2}$ VII, Leiden 1993, pp. 932-933.

ČAGMAN, F. - TANINDI, Z.

1986 Topkapi. The Albums and Illustrated Manuscripts, London 1986.

CANBY, Sh.R.

1990 Persian Masters, Five Centuries of Painting, Bombay 1990.

1993 Persian Painting, London 1993.

CANBY, Sh.R. - ThOMPSOn, J. (eds.)

2004 A caccia in paradiso. Arte di corte nella Persia del Cinquecento, Milano 2004.

Curatola, G.

1993 Frammento di tessuto: G. Curatola (ed.), Eredità dell'Islam, Arte islamica in Italia, Venezia 1993, pp. 428-429.

EkHtiar, M. - SouceK, P. - CANBy, Sh.R. - NAJAT HAidAR, N. (eds.)

2011 Masterpieces from the Department of Islamic Art in The Metropolitan Museum of Art, New York 2011.

ETTINGHAUSEN, R.

$1954 \quad$ Notes on the Lusterware of Spain: Ars Orientalis 1 (1954), pp. 133-156.

1962 La peinture arabe, Genève 1962.

FEHERVARI, G.

1985 La ceramica islamica, Milano 1985.

FIRDAWSĪ

1905 The Shàhnàma of Firdausì, done into English by Arthus George Warner, M.A. and Edmond Warner, B.A., 7 vols., London 1905.

FIRDAWSī

1976 Le Livre des rois par Abou'lkasim Firdousi publié, traduit et commenté par M. Jules Mohl, 7 vols., Paris 1976 ( $1^{\text {st }}$ edition Paris 1838-1878).

GRUBE, E.J.

1972 Islamic Paintings from the $11^{\text {th }}$ to the $18^{\text {th }}$ Century in the Collection of Hans P. Kraus, New York 1972. 
1974 Four Pages from a Turkish $16^{\text {th }}$ Century Shahnamah in the Collection of the Metropolitan Museum of Art in New York: J. M. BARRAL (ed.), Orientalia Hispanica Sive Studia F. M. Pareja Octogenario Dicata, Vol. 1, Leiden 1974. IBN BATTTUTṬA

$1874 \quad$ Voyages d'Ibn Batoutah, texte arabe, accompagné d'une traduction par C. Defremery et le D. B.R. Sanguinetti, 4 vols., Paris 1874.

Khadduri, M. - CAHEN, C. - AyAlon, D. - PARRy, V.J. - Bosworth, C.E. - Rizvi, S.A.A., BurtonPAGE, J.

1971 Harb: Encyclopaedia of Islam² III, Leiden 1971, pp. 180-203.

KomarofF, L. - CARBONI, S.

2002 The Legacy of Genghis Khan, Courtly Art and Culture in Western Asia, 1256-1353, New York 2002.

LAMMENS, H.

$1928 \quad$ L’Arabie occidentale avant l'Hégire, Beirut 1928.

LANE, E.W.

$1968 \quad$ An Arabic-English Lexicon, Beirut 1968.

MORGENSTERN, J.

1942 The Ark, the Ephod, and the "Tent of Meeting": Hebrew Union College Annual 17

Pellat, Ch. (1942), pp. 153-266.

1971 Ibil: Encyclopaedia of Islam ${ }^{2}$ III, Leiden 1971, pp. 665-669.

Pope, A.U. - ACKerman, Ph. (eds.)

1938-1939 A Survey of Persian Art, from Prehistoric Times to the Present, London 1938-1939.

ROGERS, J.M.

2000 The Arts of Islam, Treasures from the Nasser D Khalili Collection, Sydney 2000.

Ruska, J. - Pellat, Ch. - Bosworth, C.E. - Meredith-Owens, G.

1965 Fīl: Encyclopaedia of Islam² II, Leiden 1965, pp. 892-895.

SiMS, E. - MARShaK, B.I. - GRUBE, E.J.

2002 Peerless Images. Persian Painting and Its Sources, New Haven 2002.

SOUDAVAR, A.

$1992 \quad$ Art of the Persian Courts, New York 1992.

SOUSTIEL, J.

1985 La céramique islamique, le guide du connaisseur, Fribourg 1985.

Suleimanov, H. - Suleimanova, F.

$1983 \quad$ Miniatures Illuminations of Amir Hosrov Dehlevi’s Works, Tashkent 1983.

1976 The Arts of Islam (Exhibition Catalogue), London 1976.

WETZSTEIN, J.G.

1878 Sitzung vom 16. November 1878: Zeitschrift für Ethnologie 10 (1878), pp. 357-408 [388401]. 
Fig. 1 - Layla visiting Majnūn in wild nature, lampas textile with embroidery - inspired by the Khamsa by Nizami - (detail), Iran (perhaps Yazd), $16^{\text {th }}-17^{\text {th }}$ century, Museo Nazionale del Bargello, Florence, inv. no. 428/F (after Curatola 1993, ill. on p. 428).

Fig. 2 - Caravan, from a manuscript of the Maqāmāt by al-Harīiñ, Iraq (Baghdad), 1237, Bibliothèque nationale de France, Paris, Ms. Arabe 5847 fol. 94v (after Ettinghausen 1962, ill. on p. 119).
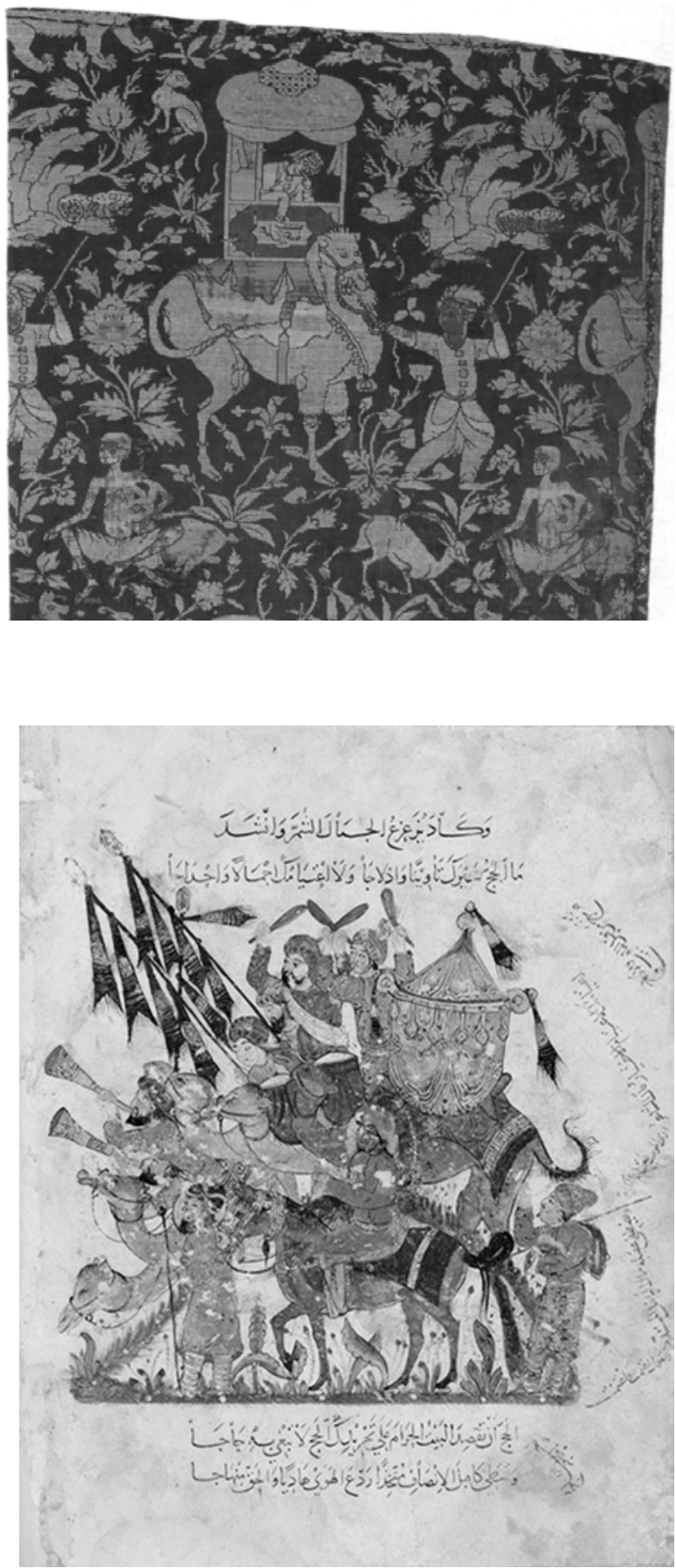

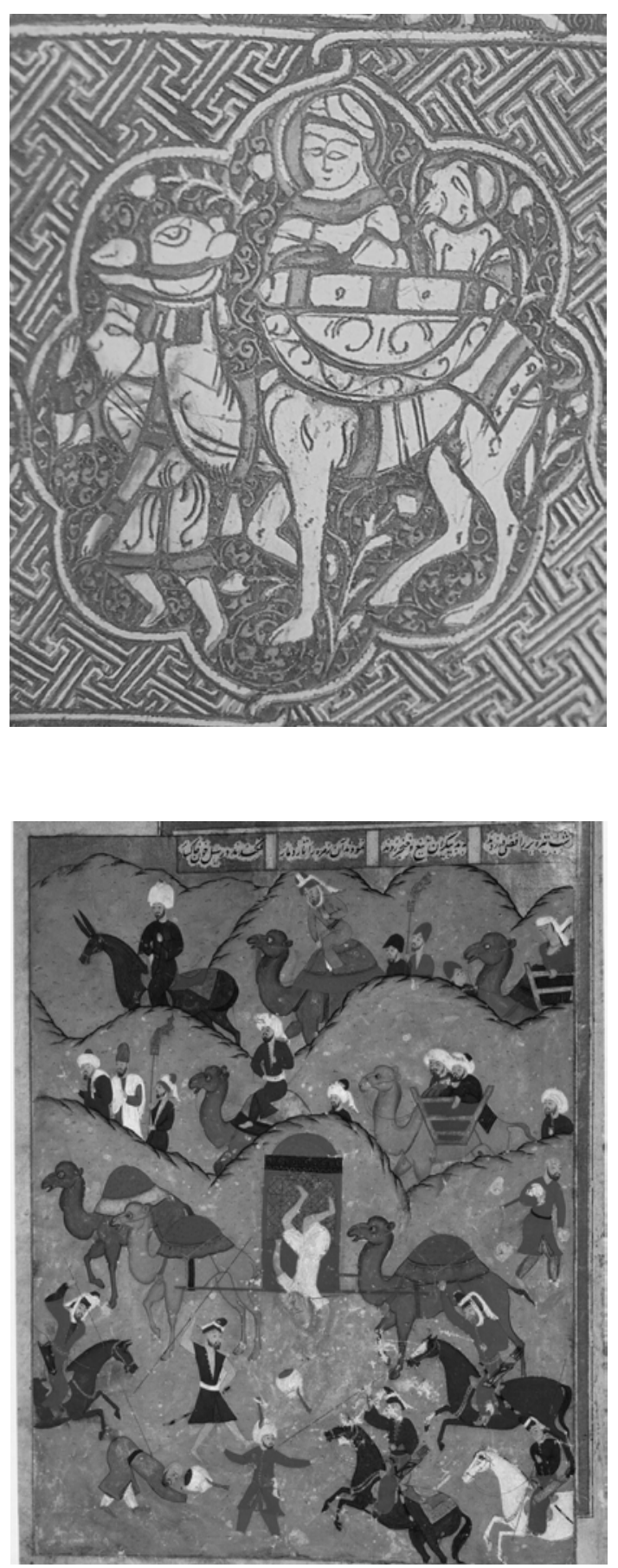

Fig. 3 - The representation of a mahāra, or "double-letter", on a brass ewer (the so-called "Blacas ewer") engraved and inlaid in silver and copper (detail), Iraq (Mosul), 1232, British Museum, London, inv. no. 66 12-69 61 (after Suleimanov - Suleimanova 1976, ill. on p. 179).

Fig. 4 - Assassination of Ma'șūm Beg on the pilgrimage road, from a manuscript of the Shāhnāma-yi Selīm Khān by Luqmān, Turkey (Istanbul), about 1571-81, Topkap1 Sarayı Library, Istanbul, A. 3595, fol. 68r (after Čagman - Tanindi 1986, ill. on p. 227). 


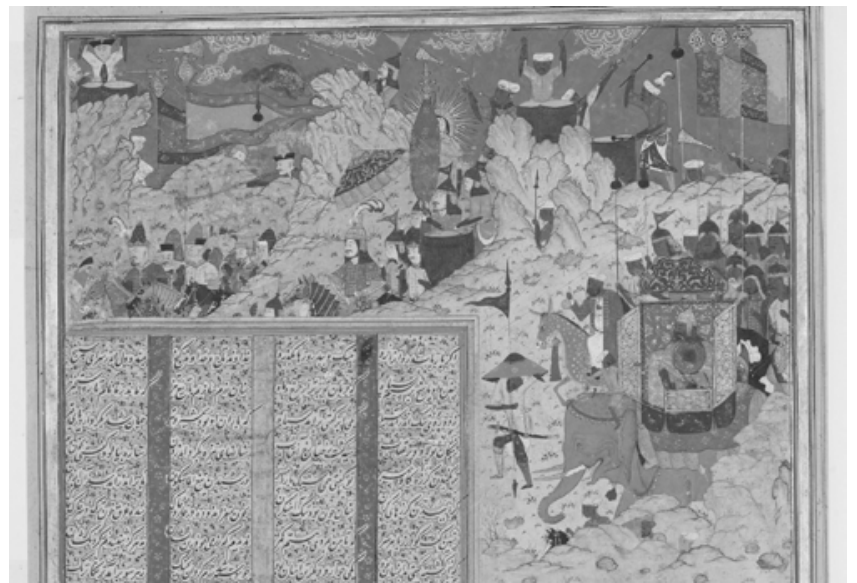

Fig. 5 - Battle between Iranians and Turanians (detail), from a manuscript of the Shāhnāma by Firdawsi, Iran (Shiraz), 1562-1583, The Metropolitan Museum of Art, New York, 52.20.9b (after Ekhtiar et al. eds. 2011, ill. on p. 217).

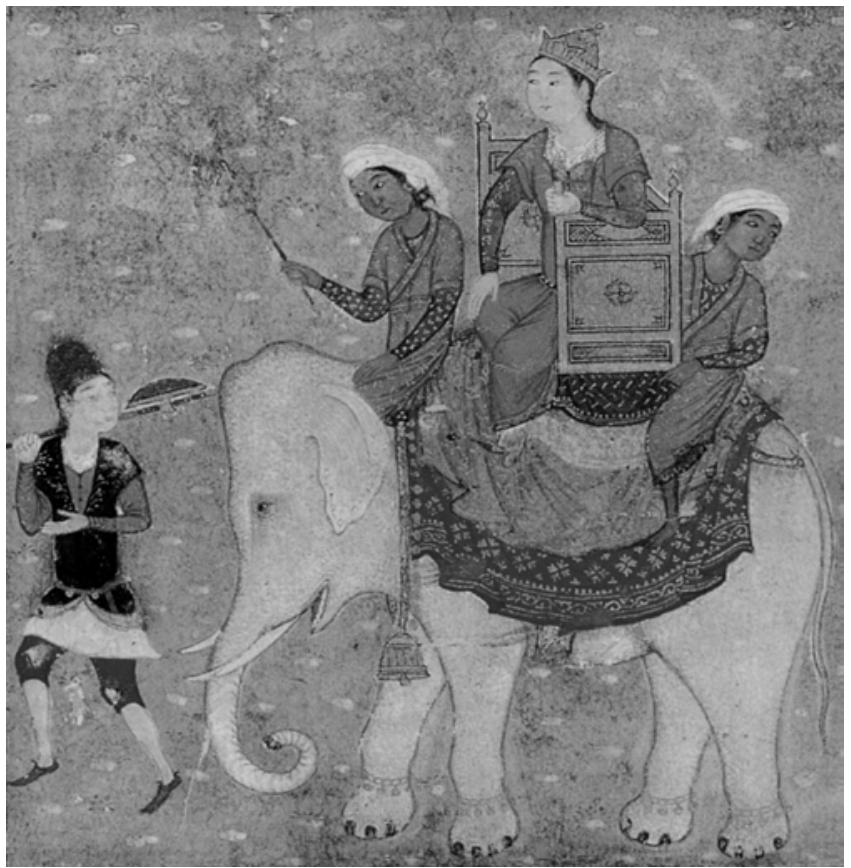

Fig. 6 - The new king parades in the city on a white elephant (detail), from a manuscript of the Kalīla wa Dimna by Abū'l-Ma'âli Nașr Allāh, Iran (Tabriz), 1410-1425, Topkapı Saray1 Library, Istanbul, H. 362, fol. 169r (after Sims et al. 2002, ill. on p. 291). 


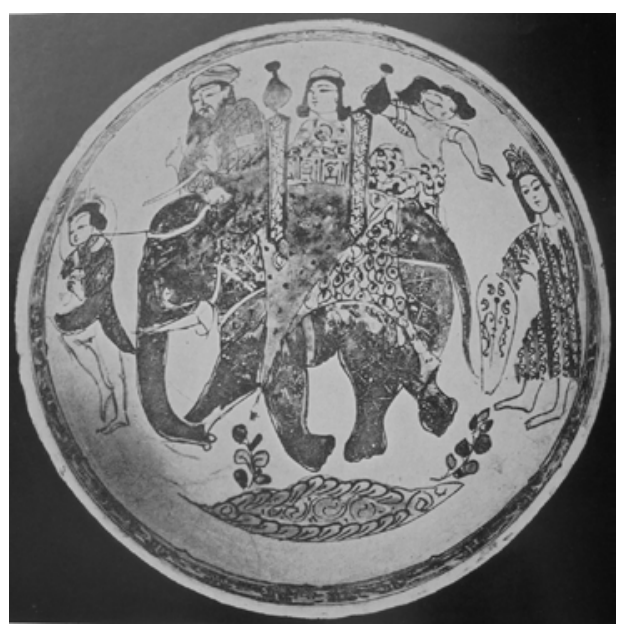

Fig. 7 - Scene with an elephant and five figures, perhaps Bahrām Gūr and Sapinūd leaving India, ceramic bowl depicted over glaze (mina $\bar{a})$ - inspired by the Shāhnāma by Firdawsi, Iran (Sava), 1220, former Moussa Collection (after Pope - Ackerman eds. 1938-1939, pl. 692.A).

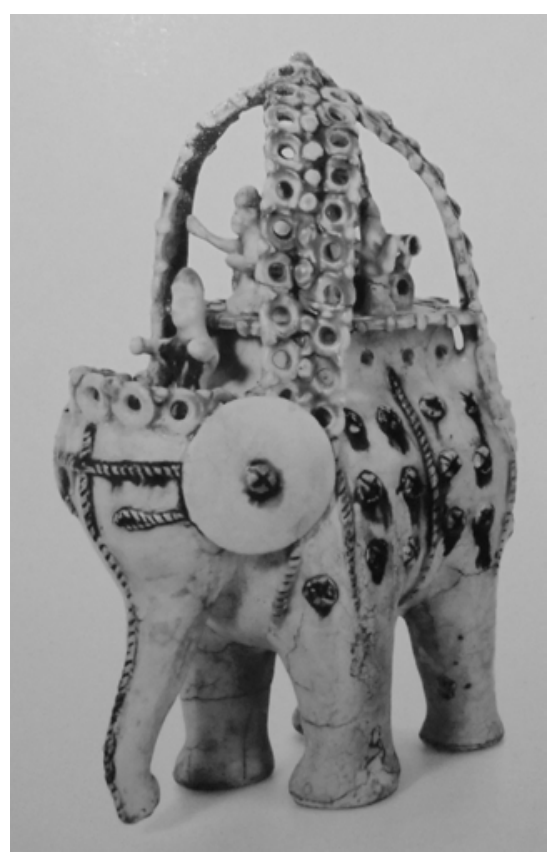

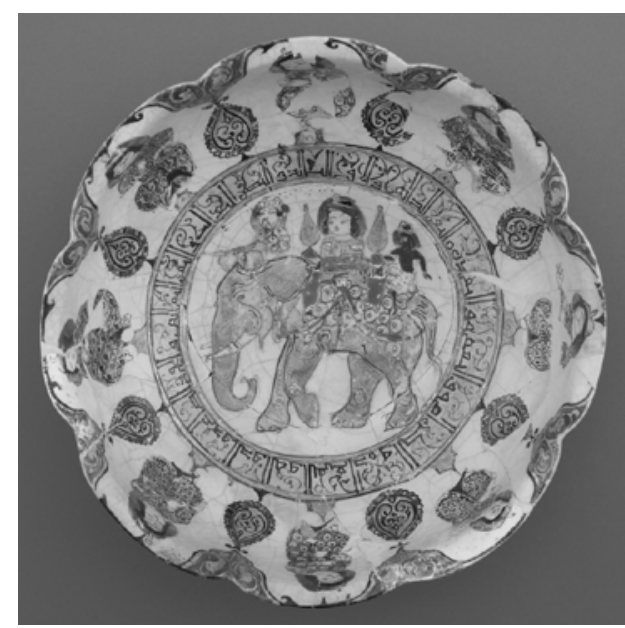

Fig. 8 - Scene with an elephant and three figures, perhaps Bahrām Gūr and Sapinūd leaving India, ceramic bowl depicted over glaze (min $\bar{a}(\vec{\imath})$ - inspired by the Shāhnāma by Firdawsi - , Iran, $12^{\text {th }}-13^{\text {th }}$ century, The Freer Gallery of Art, Washington D.C., inv. no. F1927.3 (after Sims et al. 2002, ill. on p. 290).

Fig. 9 - Elephant with open-work hawda, ceramic figurine with opaque glaze, painted in-glaze, Syria, $12^{\text {th }}-13^{\text {th }}$ century, Art Gallery of New South Wales, Sydney, inv. no. POT 1285 (after Rogers 2000, ill. on p. 103). 